\title{
Evaluation of Tumor Cell Infiltration to the Skull in Dermatofibrosarcoma Protuberans of the Scalp: Case Report and Literature Review
}

\author{
Takeshi HONGO, ${ }^{1}$ Taishi NAKAMURA, ${ }^{1}$ Akio MIYAKE, ${ }^{2}$ Ikuma KATO, ${ }^{2,3}$ \\ Kensuke TATEISHI, ${ }^{1}$ Shoji YAMANAKA, ${ }^{2}$ and Tetsuya YAMAMOTO $^{1}$ \\ ${ }^{1}$ Department of Neurosurgery, Graduate School of Medicine, Yokohama City University, \\ Yokohama, Kanagawa, Japan \\ ${ }^{2}$ Department of Pathology, Yokohama City University Hospital, Yokohama, \\ Kanagawa, Japan \\ ${ }^{3}$ Department of Pathology, Yokohama City University, Yokohama, Kanagawa, Japan
}

\begin{abstract}
Dermatofibrosarcoma protuberans (DFSP) originates from the dermal layer of the skin; the optimum treatment is an extended marginal resection. We describe a case of DFSP of the scalp with a skull invasive defect that was thoroughly examined pathologically to determine the optimum length of surgical margins. The tumor cells infiltrated up to $26 \mathrm{~mm}$ into the dermal tissues, whereas no infiltrating tumor cells were present in the skull, indicating the combination of marginal resection of the dermal tissues and lower of the skull can be a clinically relevant strategy for treatment of DFSP cases with skull invasion.
\end{abstract}

Keywords: dermatofibrosarcoma protuberans, skull, scalp, surgical resection

\section{Introduction}

Dermatofibrosarcoma protuberans (DFSP), a rare soft tissue neoplasm, originates from the dermal layer of the skin. The main etiological factor in the development of DFSP is the presentation of several prior traumas, including surgical and trauma scars, burns, and insect bites. ${ }^{1)}$ DFSP usually occurs in young to middle-aged patients but can present in all age groups. ${ }^{2)}$ It is commonly found on the trunk; however, it can also develop in the extremities, head or neck. DFSP demonstrates local infiltrative growth but seldom metastasizes distally. ${ }^{3)}$ The diagnosis and optimum treatment of DFSP are usually by pathological examinations and extended resection, respectively. The mainstay of DFSP treatment is

Received August 25, 2020; Accepted October 19, 2020

Takeshi Hongo and Taishi Nakamura equally contributed to this manuscript.

Copyright $\subseteq 2021$ by The Japan Neurosurgical Society This work is licensed under a Creative Commons AttributionNonCommercial-NoDerivatives International License. surgical, with tumor size and anatomic site being recognized as important factors influencing choice of adjuvant radiation. ${ }^{4)}$ Radiation is usually reserved for large or recurrent DFSP tumors and is most effective in reducing the rate of recurrence after surgery on large tumors. ${ }^{5)}$ In addition, adjuvant radiation therapy is most often used in cases where resection is limited due to anatomic site of the head and neck. In conventional extended resection surgeries, a $30-\mathrm{mm}$ dermal resection margin is recommended. ${ }^{6)}$ On the other hand, compared to DFSP in the trunk or extremities, DFSP in the head has extremely high local recurrent rates, ranging from $50 \%$ to $75 \% .{ }^{7)}$ However, few reports referring to the resection margin of skull invasion exist.

In this report, we present a case of DFSP of the scalp with skull defect that was thoroughly examined pathologically to know the optimum length of surgical margins, especially in the cases with skull invasion.

\section{Case Description}

A 24-year-old male presented with a subcutaneous mass on the occipital region of his head, which 
he noticed after a blunt injury occurred 12 months earlier. He described that the mass only recently started increasing prior to his visit to the clinic. Upon physical examination, an oval elastic soft mass was observed in the subcutaneous layer of the occipital region (Fig. 1A). Computed tomography (CT) of the head revealed that a $15-\mathrm{mm}$ diameter round skull defect was located just beneath the mass (Figs. 1B and 1C) and demonstrated heterogeneous enhancement of the subcutaneous mass (Fig. 1D). In three-dimensional CT imaging, the superior sagittal sinus (SSS) ran underneath the skull defect (Fig. 1E). The selective occipital artery angiogram revealed the development of feeding arteries around the mass (Fig. 1F). And there was no connection between superior sigmoid sinus and tumor (Fig. 1G). Laboratory analysis on his blood sample revealed no abnormalities in coagulation or hematological values. First, an atypical growing hematoma was suspected, and the mass was surgically removed (Fig. 2A). The tumor was hemorrhagic with a heterogeneous red color; the boundary was unclear with normal dermal tissues. Before the removal procedure, bilateral occipital arteries were ligated to control bleeding (Fig. 2B) and the mass was mostly resected (Fig. 2C). Artificial bone was applied to the skull defect, and the surface was formed smoothly. A pathological examination on the tissues revealed the presence of DFSP and positive surgical margins. As a result, the patient was scheduled for radical resection as the optimum surgical treatment. A contrast-enhanced magnetic resonance imaging (MRI) of the head was performed before the second operation; the dura mater beneath the skull defect was thickened and enhanced reactively, but no brain invasions were observed. A month later with pathological diagnosis of DFSP, in the second operation, the tumor was resected by wide excision with $30 \mathrm{~mm}$ margins with the local skin, subcutaneous tissue, and periosteum removed together (Fig. 2D). The cranial bone was also retracted with a $20 \mathrm{~mm}$ margin from the skull defect edge. Though dura matter beneath the skull defect was slightly discolored (Fig. 1B), normal color dura tissue was identified with scraping off the thickened surface. Skin and skull defects were reconstructed using a flap from the latissimus dorsi muscle. After the second surgery, the patient has been stable up to 14 months without recurrence.

\section{Pathological findings}

In the pathological examination, the tumor sample resected showed proliferations of monomorphic spindle cells of DFSP with a high nucleus/cytoplasm (N/C) ratio and Ki-67 labeling index (Fig. 3A). Immunohistochemical (IHC) analysis showed diffusely positive expressions of CD34 (Fig. 3B). DFSP is characterized by formation of the collagen type I-a1/ platelet-derived growth factor-b (COL1A1-PDGFB) fusion gene resulting in the constitutive upregulation of PDGFB expression. ${ }^{8)}$ In this case, fluorescence in situ hybridization (FISH) using a dual-color breakapart probe of PDGFB demonstrated split signals with amplification, which indicated an unbalanced translocation covering the region (Fig. 3C).

The skin and skull resected during the second operation were multiply sliced and were subjected to thorough pathological examination. The surgical margin of the resected skin was pathologically negative (Fig. 3D). The tumor cells infiltrated up to $26 \mathrm{~mm}$ (range: $0-26 \mathrm{~mm}$ ) from the macroscopic tumor edge in subcutaneous tissues. In multisliced subcutaneous specimen, the invasion front of tumor cells showed continuity from the main mass without isolated tumor cells. While no infiltration tumor cells were observed in both cortical and cancellous bones, even around the edges of the region of the skull with defects (Fig. 3E). Together, we confirmed pathologically negative findings in the surgical margins of the skin and cranial bone of this patient.

\section{Discussion}

DFSP is characterized by a low metastasis and high growth rates, which may determine high levels of local invasion recurrence. Some reports indicate that conventional surgery leads to local recurrence in up to $30 \%$ of cases, and compared to DFSPs in the trunk or extremities, DFSPs in the head region have extremely high, ranging from $50 \%$ to $75 \%$ local recurrence rates. ${ }^{7-9)}$ There is no report mentioning to the extent of infiltration of DFSP tumor cell into the skull pathologically. A radical skull resection for recurrent DFSP in the scalp was reported to have shown low clinical local recurrent rates with marginal resection of $20 \mathrm{~mm}$ in the cranial bone and we performed the same distant margins and analyzed the pathological infiltration to the skull in this case. ${ }^{10)}$ In our case, no tumor cells infiltrating bone tissues around the skull defect edge were present in detailed pathological analysis. We suppose that the difference in the invasiveness into normal tissues is due to tumor origin and affinity, as is noted in other malignant tumors. ${ }^{11}$ 

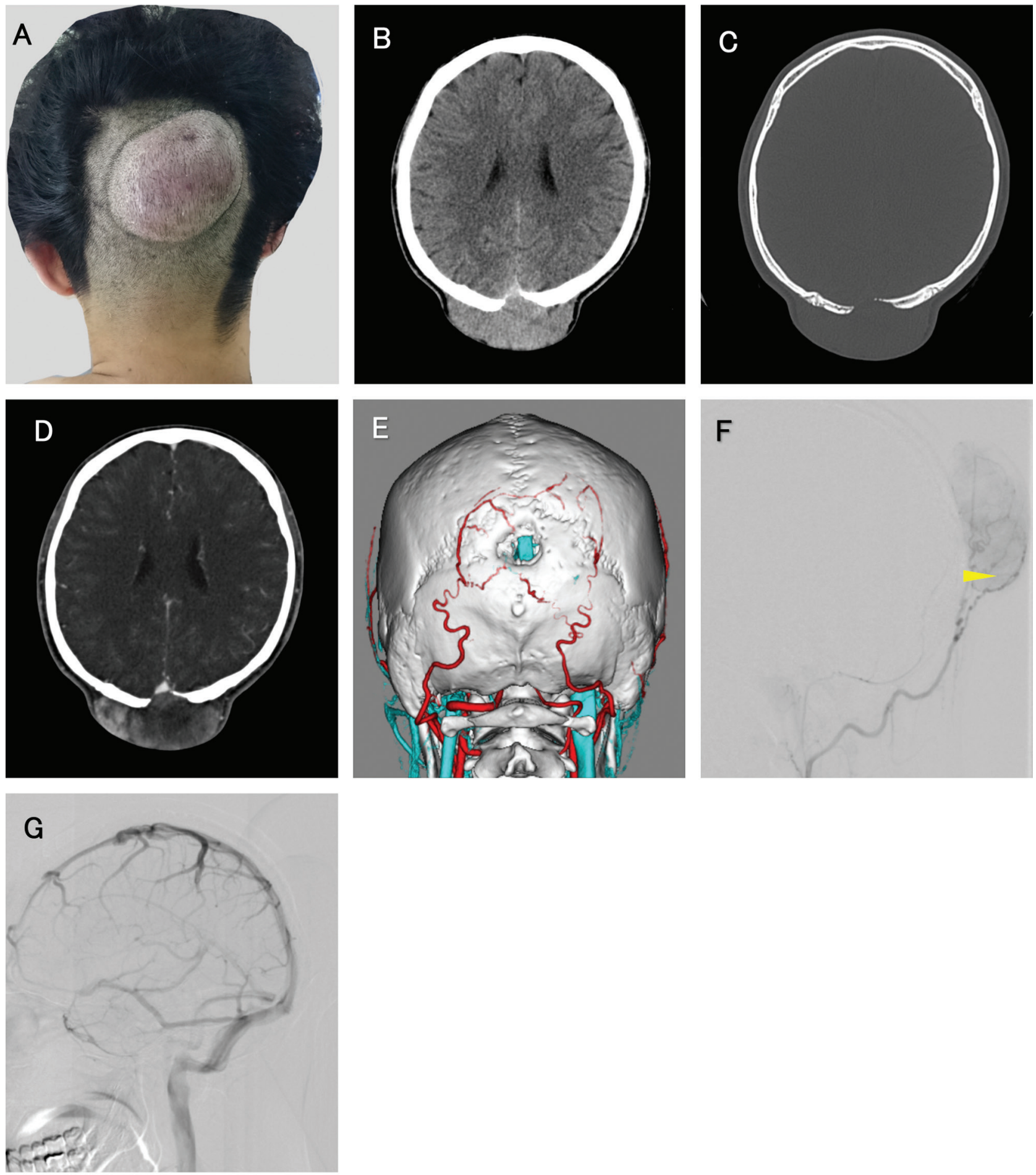

Fig. 1 Pre-therapeutic images. (A) The mass was soft with mild tenderness in the midline occipital region of the scalp $(80 \times 80 \mathrm{~mm})$. (B, C) The tumor showed no calcification; bone destruction was observed subcutaneously in the occipital cranial bone corresponding to the tumor. (D) On iopamidol-enhanced CT of the tumor showed heterogeneous enhancement. (E) In three-dimensional CT imaging, the skull defect presented above SSS. (F) Selective occipital artery angiography showed multiple feeding arteries for the tumor (arrowhead). (G) There was no connection between superior sigmoid sinus and tumor. CT: computed tomography, SSS: superior sagittal sinus. 

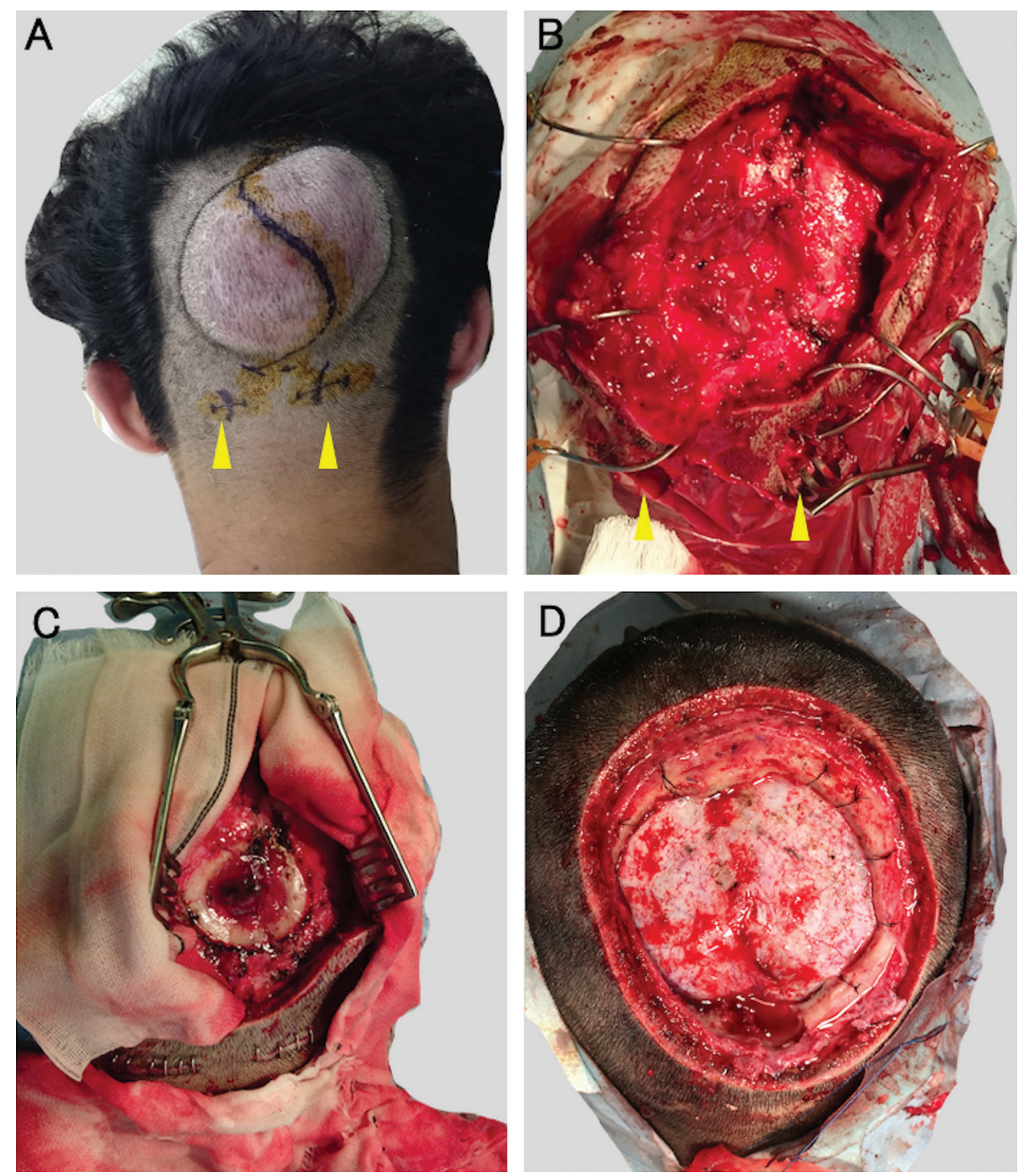

Fig. 2 Preoperative preparation and operative findings. (A) Sigmoid-shaped skin incision was designed and the stream of bilateral occipital arteries (arrowheads) were identified preparing for ligation. (B) Tumor is of an intradermal origin showing a heterogeneously red color, easily hemorrhagic. Bilateral occipital arteries (arrowheads) were ligated in order to control bleeding. (C) A surgical view after the mass debulking. (D) The surgical view of marginal resection of the skin and the cranial bone in the 2 nd operation.

We also performed PubMed search for accessing the MEDLINE database using the terms "dermatofibrosarcoma protuberans" and "scalp" to review the surgical strategies for DFSP patients in the scalp with periosteum, skull, or intracranial invasion. In all, 74 articles were collected on DFSP of the scalp, and we reviewed articles with descriptions about periosteum, skull, and intracranial invasion. Tumor extension from the scalp into the intracranial space is very rare, and to the best of our knowledge, only 17 cases have been reported, which fulfilled the conditions above. Clinical data are summarized in Table 1 with our case. ${ }^{10-26)}$ According to the review, dermal resection with periosteum was an accepted strategy with good local control if the tumor invasion was limited within periosteum. In the four reported DFSP patients whose invasion were limited within periosteum, there were no recurrence in the follow-up periods (range: 4-156 months). There were five DFSP cases with follow-up results whose invasion were limited within skull. Four patients among the five cases got surgery with marginal resection of the skull, which showed better local control 

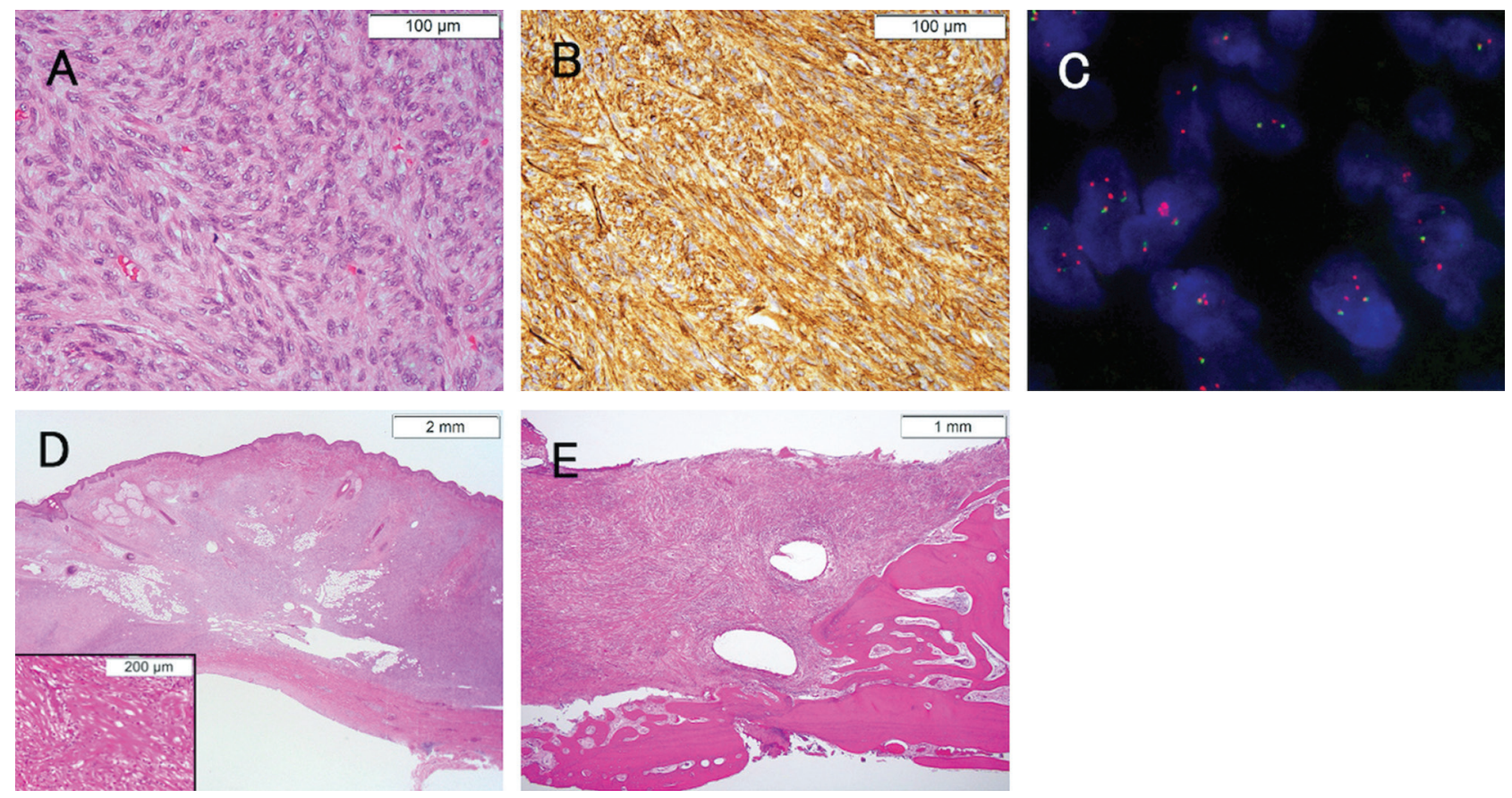

Fig. 3 (A) Histopathological findings. Proliferation of monomorphic spindle cells showing storiform pattern was observed by hematoxylin and eosin staining. (B) Immunostaining for CD34 was positive and the tumor cells showed staining around the cell membrane and cytoplasm. (C) Split and amplified signals of PDGFB were observed by FISH using a dual-color break apart probe. (D) The tumor cells spread diffusely in subcutaneous tissues in the horizontal direction. (E) At the vertical margin, the pericranium was not invaded. The tumor cells were not found in the bone defect edge that was replaced by the granulation tissue, including blood vessels, fibroblasts, and lymphocytes. FISH: fluorescence in situ hybridization, PDGFB: platelet-derived growth factor-b.

comparing to a patient with no marginal resection of the skull (she developed another recurrence in 3 months after the surgery).

Most cases in the review were recurrent tumor cases, so we considered why only a few cases with skull invasion were reported at initial presentation. According to the reports, the main reason seemed that DFSP was not anticipated and surgical resection was initially performed without margin for the mass, which resulted in recurrence of the local area. And when the patients recurred, they are often introduced to specific institutes for advanced medical service.

This case report is the first to analyze the extent of invasion of DFSP tumor cells into the skull pathologically. These findings indicate that the combination of extended resection of the dermal and lower margins of the skull can be a clinically relevant strategy for treatment of DFSP cases in the head with skull defect, which is clinically significant and has the potential to inform strategies that may possibly reduce surgical invasiveness.

\section{Ethical Approval}

All procedures performed in studies involving human participants were in accordance with the ethical standards of the institutional with the Helsinki declaration and its later amendments or comparable ethical standards. Informed consent was obtained from the individual participant included in the study.

\section{Funding}

This study was partially funded by KAKENHI Grants-in-Aid for Scientific Research, [18K16565 (T.N.)] and received no specific grant from any funding agency in commercial or not-for-profit sectors.

\section{Conflicts of Interest Disclosure}

All authors certify that they have no affiliations with or involvement in any organization or entity with any financial interest, or non-financial interest 


\begin{tabular}{|c|c|c|c|c|c|c|c|c|}
\hline Study & $\begin{array}{l}\text { Age } \\
\text { (year), } \\
\text { sex }\end{array}$ & $\begin{array}{l}\text { Primary/ } \\
\text { reccurent }\end{array}$ & $\begin{array}{l}\text { Single/ } \\
\text { multiple }\end{array}$ & $\begin{array}{l}\text { Tumor size } \\
(\mathrm{mm})\end{array}$ & Skin margin (mm) & $\begin{array}{l}\text { Pericranium/ skull/ } \\
\text { intracranial invasion }\end{array}$ & Skull margin (mm) & $\begin{array}{l}\text { PFS, follow-up } \\
\text { (month) }\end{array}$ \\
\hline Rockley et al., 1989 & $23, \mathrm{~F}$ & $\mathrm{P}$ & $\mathrm{S}$ & $80 \times 110$ & 30 & Yes (periosteum invasion) & Periosteum resection & 22 (no reccurence) \\
\hline \multirow[t]{2}{*}{ Loss et al., 2005} & $26, \mathrm{~F}$ & $\mathrm{R}$ & $\mathrm{S}$ & $10 \times 8$ & $25-30$ & Yes (periosteum invasion) & Periosteum resection & 156 (no reccurence) \\
\hline & $33, \mathrm{~F}$ & $\mathrm{P}$ & $\mathrm{S}$ & $50 \times 10$ & Mohs & Yes (periosteum invasion) & Periosteum resection & 4 (no reccurence) \\
\hline Arifin et al., 2014 & $26, \mathrm{M}$ & $\mathrm{R}$ & S & $70 \times 60 \times 50$ & 20 & Yes (periosteum invasion) & Periosteum resection & 12 (no reccurence) \\
\hline $\begin{array}{l}\text { McLoughlin et al., } \\
1992\end{array}$ & $76, \mathrm{~F}$ & $\mathrm{R}$ & $\mathrm{S}$ & 5 & 30 & Yes (skull invasion) & $\begin{array}{l}\text { No marginal } \\
\text { resection }\end{array}$ & ND \\
\hline Sinha et al., 2001 & $45, \mathrm{M}$ & $\mathrm{R}$ & $\mathrm{S}$ & ND & 30 & Yes (skull invasion) & 30 & 4 (no reccurence) \\
\hline Kim et al., 2007 & $30, \mathrm{~F}$ & $\mathrm{R}$ & S & $60 \times 40 \times 60$ & 20 & Yes (skull invasion) & 20 & 24 (reccurence) \\
\hline Bhatnagar et al., 2013 & $35, \mathrm{M}$ & $\mathrm{R}$ & $\mathrm{S}$ & $80 \times 80$ & 50 & Yes (skull invasion) & 30 & 6 (no reccurence) \\
\hline Liansheng et al., 2014 & $26, \mathrm{~F}$ & $\mathrm{R}$ & ND & $90 \times 90$ & $\begin{array}{l}\text { No marginal } \\
\text { resection (patient's } \\
\text { demand) }\end{array}$ & Yes (skull invasion) & $\begin{array}{l}\text { No marginal } \\
\text { resection }\end{array}$ & 3 (reccurence) \\
\hline \multirow[t]{2}{*}{ Faried et al., 2017} & $29, \mathrm{M}$ & $\mathrm{R}$ & $\mathrm{S}$ & ND & 40 & Yes (skull invasion) & At least 30 & ND \\
\hline & $49, \mathrm{M}$ & $\mathrm{R}$ & $\mathrm{S}$ & ND & 40 & Yes (skull invasion) & At least 30 & ND \\
\hline Present case & $24, \mathrm{M}$ & $\mathrm{P}$ & $\mathrm{S}$ & $80 \times 80$ & 30 & Yes (skull invasion) & 20 & 12 (no reccurence) \\
\hline Burkhardt et al., 1966 & $35, \mathrm{M}$ & $\mathrm{R}$ & M & ND & Not operated & Yes (intracranial invasion) & Not operated & Within 36 (death) \\
\hline Rockley et al., 1989 & $35, \mathrm{~F}$ & $\mathrm{R}$ & M & $70 \times 60 \times 30$ & ND & Yes (intracranial invasion) & ND & $\begin{array}{c}\text { Intraoperative } \\
\text { death }\end{array}$ \\
\hline Das et al., 2000 & $40, \mathrm{M}$ & $\mathrm{R}$ & $\mathrm{S}$ & $100 \times 100$ & 30 & Yes (intracranial invasion) & ND & ND \\
\hline Taniguch et al., 2002 & $39, \mathrm{M}$ & $\mathrm{R}$ & M & ND & $\begin{array}{l}\text { No marginal } \\
\text { resection }\end{array}$ & Yes (intracranial invasion) & $\begin{array}{l}\text { No marginal } \\
\text { resection }\end{array}$ & 12 (death) \\
\hline Uematsu et al., 2003 & $49, \mathrm{M}$ & $\mathrm{R}$ & $\mathrm{S}$ & ND & $\begin{array}{l}\text { No marginal } \\
\text { resection }\end{array}$ & Yes (intracranial invasion) & $\begin{array}{l}\text { No marginal } \\
\text { resection }\end{array}$ & $\begin{array}{l}5 \text { (reccurence), } \\
66 \text { (death) }\end{array}$ \\
\hline Marakovic et al., 2008 & $41, \mathrm{M}$ & $\mathrm{R}$ & S & ND & ND & Yes (intracranial invasion) & $\begin{array}{l}\text { Resected "margin } \\
\text { around the } \\
\text { infiltrated region" }\end{array}$ & 8 (reccurence) \\
\hline Abe et al., 2009 & $22, \mathrm{M}$ & $\mathrm{R}$ & $\mathrm{S}$ & $80 \times 80 \times 70$ & ND & Yes (intracranial invasion) & ND & $\begin{array}{l}18 \text { (reccurence), } \\
145 \text { (death) }\end{array}$ \\
\hline Sangrador et al., 2019 & $25, \mathrm{~F}$ & $\mathrm{P}$ & S & $125 \times 105 \times 80$ & ND & Yes (intracranial invasion) & $\begin{array}{l}\text { No marginal } \\
\text { resection }\end{array}$ & ND \\
\hline
\end{tabular}


in the subject matter or materials discussed in this manuscript.

\section{References}

1) Stivala A, Lombardo GA, Pompili G, et al.: Dermatofibrosarcoma protuberans: our experience of 59 cases. Oncol Lett 4: 1047-1055, 2012

2) Al-Rahbi $S$, Al-Lawati T, Al-Kharusi $S$, Thomas $S$, Al-Harrasi K: Dermatofibrosarcoma protuberans: a rare malignancy of the breast. Oman Med $J 30$ : 378-381, 2015

3) Bogucki B, Neuhaus I, Hurst EA: Dermatofibrosarcoma protuberans: a review of the literature. Dermatol Surg 38: 537-551, 2012

4) Criscito MC, Martires KJ, Stein JA: Prognostic factors, treatment, and survival in dermatofibrosarcoma protuberans. JAMA Dermatol 152: 1365-1371, 2016

5) Llombart B, Serra-Guillén C, Monteagudo C, Guerrero JAL, Sanmartín O: Dermatofibrosarcoma protuberans: a comprehensive review and update on diagnosis and management. Semin Diagn Pathol 30: 13-28, 2013

6) Serra-Guillén C, Llombart B, Nagore E, et al.: Mohs micrographic surgery in dermatofibrosarcoma protuberans allows tumour clearance with smaller margins and greater preservation of healthy tissue compared with conventional surgery: a study of 74 primary cases. British J Dermatol 172: 1303-1307, 2015

7) Barnes L, Coleman JA, Johnson JT: Dermatofibrosarcoma protuberans of the head and neck. Arch Otolaryngol 110: 398-404, 1984

8) Zhang Z, Chen H, Chen M, et al.: Application of COL1A1-PDGFB fusion gene detection by fluorescence in situ hybridization in biopsy tissue of dermatofibrosarcoma protuberans. J Dermatol 44: 798-802, 2017

9) Sanmartín O, Llombart B, López-Guerrero JA, Serra C, Requena C, Guillén C: Dermatofibrosarcoma protuberans. Actas Dermosifiliogr 98: 77-87, 2007

10) Faried A, Hadisaputra W, Arifin MZ: Recurrence case of rare scalp dermatofibrosarcoma protuberans: two case reports of a wide radical excision, craniectomy bone involvement followed by cranioplasty and reconstruction. Surg Neurol Int 8: 82, 2017

11) Tickle C, Crawley A, Goodman M: Cell movement and the mechanism of invasiveness: a survey of the behaviour of some normal and malignant cells implanted into the developing chick wing bud. $J$ Cell Sci 31: 293-322, 1978

12) Abe T, Kamida $T$, Goda $M$, et al.: Intracranial infiltration by recurrent scalp dermatofibrosarcoma protuberans. J Clin Neurosci 16: 1358-1360, 2009
13) Arifin MZ, Yudoyono F, Dahlan RH, Hernowo BS, Sutiono AB, Faried A: A rare giant scalp dermatofibrosarcoma protuberans. Surgical Neurol Int 5, 2014

14) Bhatnagar A, Srivastava A, Sahu RN: Management of recurrent dermatofibro sarcoma protuberance of scalp-a reconstructive challenge. Indian J Surg Oncol 4: 15-18, 2013

15) Burkhardt BR, Soule EH, Winkelmann RK, Ivins JC: Dermatofibrosarcoma protuberans: study of fifty-six cases. Am J Surg 111: 638-644, 1966

16) Das L, Grover SB, Chand K, Dawson L: Intracranial extension of a dermatofibrosarcoma protuberans of the scalp: a case report with brief review of literature. Surg Neurol 54: 452-454, 2000

17) Kim SD, Park JY, Choi WS, Kim SH, Lim DJ, Chung HS: Intracranial recurrence of the scalp dermatofibrosarcoma. Clin Neurol Neurosurg 109: 172-175, 2007

18) Liansheng L, Xialiang L, Yaodong Z, Yajun X, Meiqing L: Report of two cases of recurrent scalp dermatofibrosarcoma protuberans and literature review. Indian J Dermatol 59: 602-605, 2014

19) Loss L, Zeitouni NC: Management of scalp dermatofibrosarcoma protuberans. Dermatol Surg 31: 14281433, 2005

20) Marakovic J, Vilendecic M, Marinovic T, Lambasa S, Grahovac G: Intracranial recurrence and distant metastasis of scalp dermatofibrosarcoma protuberans. J Neurooncol 88: 305-308, 2008

21) McLoughlin PM, Girach M, Wood GA: Dermatofibrosarcoma protuberans of the scalp. Br J Oral Maxillofac Surg 30: 401-403, 1992

22) Rockley PF, Robinson JK, Magid M, Goldblatt D: Dermatofibrosarcoma protuberans of the scalp: a series of cases. J Am Acad Dermatol 21: 278-283, 1989

23) Sinha VD, Dharker SR, Kalra GS: Dermatofibrosarcoma protuberans of scalp: a case report. Neurol India 49: 81-83, 2001

24) Uematsu Y, Fukai J, Tamura M, et al.: Distant metastasis of dermatofibrosarcoma protuberans of the scalpcase report. Neurol Med Chir (Tokyo) 43: 493-496, 2003

25) Sangrador M, Olvera JG, Ortiz VM: Dermatofibrosarcoma of the scalp. Surgical Neurol Int 10: 2019.

26) Taniguchi $Y$, Tamaki $T$, Yoshida M, Uematsu Y: Reconstruction of a scalp and skull defect with free latissimus dorsi myocutaneous flap following dermatofibrosarcoma protuberans. J Orthop Surg (Hong Kong) 10: 206-209, 2002

Corresponding author: Taishi Nakamura, MD, PhD Department of Neurosurgery, Graduate School of Medicine, Yokohama City University, 3-9 Fukuura, Kanazawa-ku, Yokohama, Kanagawa 236-0004, Japan. e-mail:n_taishi@yokohama-cu.ac.jp 